Research Note

Journal of Extension Education

Vol. 29 No. 2, 2017

DOI:https: / / doi.org/10.26725/JEE.2017.2.29.5875-5879

\title{
Role of Social Media as Communication Channel for Veterinary Extension Workers
}

\section{S.Vigil Anbiah ${ }^{1}$ and R.Vijayalakshmi ${ }^{2}$}

\begin{abstract}
A study was conducted to assess the role of social media networks for effective digital communication among the veterinary extension workers. The study involved assessing the role and constraints of a social media group named as veterinary technical forum in the context of enhancing quality health service to the livestock by active networking with other experts of the world. It is concluded that the most important role of social media was the commonality of interest which could be achieved in sharing of knowledge. Lack of broadband services in remote locations was considered as the major constraints in adopting social media as a communication channel for veterinary extension works.
\end{abstract}

Keywords : Social Media; Veterinary Extension professionals; constraints

The most important issue with extension mechanism is the lack of technical human resource. A large number of positions in public extension system in India are vacant, leaving the extension workers personnel to overwork, thus decreasing their efficiency (Mukherjee and Maity, 2015). Unique mobile user penetration in 2016-2017 has been 35 per cent, whereas the mobile's share of web traffic is 79 per cent. India's internet users grew by 40 per cent while globally the growth was of 9 per cent, making the growth 4 times higher in India (ETtech, 2016). Social media penetration is 14 per cent while growth of social media users in 2016-2017 has been 40 per cent (55 million), which is second highest in the world. Social media platforms like Facebook, YouTube, Twitter and Google+ have higher levels of use among Indians compared to US, UK and European countries. These developments have opened up new avenues for improving reach of extension services for the needy farmers and other stakeholders.

Keeping this in view, a study was conducted on a social media network group called as "Veterinary Technical Forum" which had its inception in the year 2011 now networking nearly 1,100 veterinarians throughout the globe

1. Head-in-Charge, Central Animal House, Rajah Muthiah Medical College, Annamalai University and 2. Associate Professor and Head, Division of Animal Husbandry, Annamalai University. Annamalai Nagar - 608 002, Tamil Nadu, India. 
for online real-time interactions and knowledge sharing in the field of animal health management.

\section{METHODOLOGY}

The study adopted a descriptive survey about "Veterinary Technical Forum", a social media closed group that caters to nearly 1,100 veterinarians throughout the globe since 2013. This forum was created to disseminate latest technologies in the field of veterinary science. Through this forum, discussions regarding livestock management, therapeutics and prophylactic measures which are used in routine livestock management are held. This group consists of government as well as private extension workers. The social media tool used for networking is facebook. The study randomly sampled 300 veterinary extension workers from various states of India who are the members of "Veterinary Technical Forum". The respondents were contacted in person. In some cases, telephonic interviews were also used for the collection of data. A well structured and pretested interview schedule was used for the collection of data. Respondents were asked to indicate the constraints they have faced while using social media as their communication channel for veterinary extension works.

\section{FINDINGS AND DISCUSSION}

The response of Veterinary Extension Workers about the role of social media as a communication channel as perceived by the Veterinary Extension Workers are furnished in Table 1.

Commonality of interest could be achieved in sharing of knowledge was perceived by 94.33 per cent of veterinary extension workers. 93.33 per cent of the veterinary extension workers felt that real-time sharing of information through social media is helpful during forecast of disasters or disease outbreaks. The view of 91.00 percent of extension workers expressed that the social media could be used to discuss about emergency health care of animals. Through video and photographs shared are helpful in understanding the latest trends in animal health management was felt by 81.00 per cent of the respondents. The social media provide tools to extension professionals for sharing information and will be a part of discussions and debates on extension as perceived by 78.66 per cent of veterinary extension workers. The constraints of social media as a communication channel as perceived by the Veterinary Extension Workers are furnished in Table 2.

Lack of broadband services in remote location provides longer downloading time for photos and videos was the top most constraint as expressed by 96.33 per cent respondents. Literacy of farmers is a concern in the usage of social media was perceived by 85.33 per cent respondents. 79 per cent of the extension workers felt that excessive time spent on social networks causes some individuals to experience withdrawal symptoms. 
Table 1.

Perception of Media as a Communication Channel for Veterinary Extension Workers

\begin{tabular}{|c|c|c|c|c|}
\hline & & & & $=300)^{*}$ \\
\hline $\begin{array}{l}\text { S1. } \\
\text { No. }\end{array}$ & Role of Social Media & $\begin{array}{l}\text { Number of } \\
\text { Respondents }\end{array}$ & Percentage & Rank \\
\hline 1. & $\begin{array}{l}\text { Commonality of interest could be achieved } \\
\text { in sharing of knowledge. }\end{array}$ & 283 & 94.33 & I \\
\hline 2. & $\begin{array}{l}\text { Real-time sharing of information through } \\
\text { the Social media is helpful during forecast } \\
\text { of disasters or disease outbreaks. }\end{array}$ & 280 & 93.33 & II \\
\hline 3. & $\begin{array}{l}\text { The Social media discuss about emergency } \\
\text { health care of animals. }\end{array}$ & 273 & 91.00 & III \\
\hline 4. & $\begin{array}{l}\text { The video and photographs shared in the } \\
\text { Social media are helpful in understanding } \\
\text { the latest trends in animal health } \\
\text { management. }\end{array}$ & 243 & 81.00 & IV \\
\hline 5. & $\begin{array}{l}\text { Social media provides tools to extension } \\
\text { professionals for sharing information and } \\
\text { to be a part of discussions and debates on } \\
\text { extension }\end{array}$ & 236 & 78.66 & V \\
\hline 6. & $\begin{array}{l}\text { The reach of extension personnel in rural } \\
\text { areas can increase manifold with the use of } \\
\text { social media. }\end{array}$ & 234 & 78.00 & VI \\
\hline 7. & $\begin{array}{l}\text { Networking, sharing ideas and opinions, } \\
\text { even conducting research can ultimately } \\
\text { help in career advancement of extension } \\
\text { professionals and they become competent } \\
\text { to serve the clients better. }\end{array}$ & 220 & 73.33 & VII \\
\hline 8. & $\begin{array}{l}\text { Social media provides insights and } \\
\text { evidences required to influence policy and } \\
\text { policymakers }\end{array}$ & 213 & 71.00 & VIII \\
\hline
\end{tabular}




\begin{tabular}{|l|l|l|l|l|}
\hline 9. & $\begin{array}{l}\text { Capacity development is another issue that } \\
\text { can be conveniently addressed through } \\
\text { social media for field functionaries, rural } \\
\text { youth and farmers }\end{array}$ & 178 & 59.33 & IX \\
\hline 10 & $\begin{array}{l}\text { Social media can be used as the common } \\
\text { platform for all stakeholders to have a } \\
\text { dialogue and increase inclusion of generally } \\
\text { disadvantaged groups like women and the } \\
\text { socially marginalized. }\end{array}$ & 143 & 47.66 & $\mathrm{X}$ \\
\hline
\end{tabular}

*Multiple responses

As per the views of respondents, the major advantages of 'Veterinary Technical Forum' are, achievement of commonality of interest, discussion about emergency health care of animals and sharing of video and photographs for better understanding of the latest trends in animal health management. However, members of 'Veterinary Technical Forum' expressed constraints such as lack of

Table 2.

\section{Constraints of Social Media as Communication Channel}

\begin{tabular}{|c|c|c|c|c|}
\hline & & & & $=300)$ \\
\hline $\begin{array}{l}\text { S1. } \\
\text { No. }\end{array}$ & Constraints & $\begin{array}{l}\text { Number of } \\
\text { Respondents }\end{array}$ & Percentage & Rank \\
\hline 1. & $\begin{array}{l}\text { Lack of broadband services in remote } \\
\text { location provides longer downloading time } \\
\text { for photos and videos }\end{array}$ & 289 & 96.33 & I \\
\hline 2. & $\begin{array}{l}\text { Literacy of farmers is a concern in the } \\
\text { usage of social media }\end{array}$ & 256 & 85.33 & II \\
\hline 3. & $\begin{array}{l}\text { Excessive time spent on social networks } \\
\text { causes some individuals to experience } \\
\text { withdrawal symptoms }\end{array}$ & 237 & 79.00 & III \\
\hline 4. & $\begin{array}{l}\text { Social media could cause more stress } \\
\text { related diseases among the users. }\end{array}$ & 185 & 61.66 & IV \\
\hline 5. & $\begin{array}{l}\text { Social media perpetuates false and } \\
\text { unreliable information to the farmers }\end{array}$ & 164 & 54.66 & V \\
\hline
\end{tabular}

*Multiple responses 
broadband services in remote location, lesser literacy among the farmers, exhibition of withdrawal symptoms in some users. Based on the study, it is concluded that there is a wider scope for active involvement of social media as an effective communication channel for extension workers.

\section{REFERENCES}

ETtech. (2016). India's internet user growth rate is $4 X$ of global rate: Mary Meeker's 2016 internet trends. Available at http:// $\mathrm{te} \mathrm{ch}$. e con o m i c t i m e s. i n d i a times. com / n e w s / internet/indias-internet-usergrowth-rate-is-4xof-global-growthrate-mary-meeker/ 52550127

Mukherjee, A \& Maity, A. (2015). Public-private partnership for convergence of extension services in Indian agriculture, Current Science, 109(9): 1557-1563. 